UNIO - EU Law Journal. Vol. 4, No. 1, January 2018, pp 16-26.

®2018 Centre of Studies in European Union Law

School of Law - University of Minho

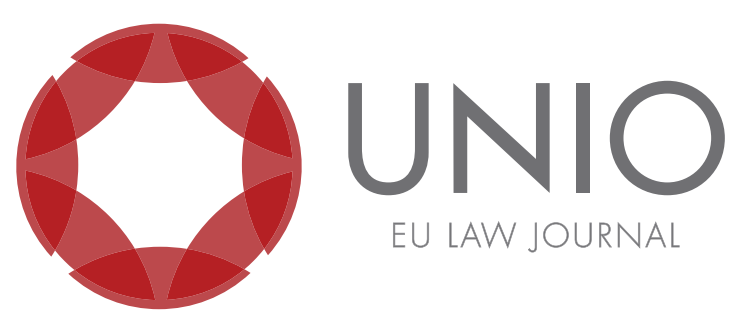

\title{
Europe - a project worthy of being built
}

\author{
Valentina Maglietta*
}

ABSTRACT: Sixty years after the emergence of the EU, it is still a challenge to educate citizens about European themes and to really involve them in the integration process. This requires the pursuit for solutions and adequate responses from institutions, among others. But, what does it mean to be a European citizen? Does it make sense to use the concept of "citizenship" beyond the national borders? With the purpose of addressing these questions, this paper is divided into three parts. The first part addresses the definition of citizenship within the borders of a Nation State and, looks at the relationship between nationality and identity emphasized by the philosopher Thomas H. Marshall. The second turns to the European citizenship, looking at the political developments under which this concept has been given greater prominence, becoming both a source of legitimation of the European integration process and a fundamental factor in the creation among citizens of a European identity. Citizenship of the Union treasures the indisputable virtue of being the first political and legal materialisation of a citizenship at a transnational level. Nevertheless, at the time like the present, when nationalist and xenophobic feelings against the EU are on the rise and national egoism is becoming an attractive alternative to integration, the European identity struggles to attain a legitimate status in the eyes of the citizenry. The challenge ahead is that we need to find a new way to narrate European integration to all those who do not feel part of this project and that do not understand the pressing need for being "united in diversity". In this achievement, the EU stakes its future. With this in mind, in the third section of the article, I propose some areas where progress should be made to encourage a greater sense of integration among European citizens.

KEYWORDS: European citizenship-public opinion - democracy - civil society - civic education.

\footnotetext{
* Holder of the scholarship for trainee academic researchers (PIF) at the Department of Political Science and Public law of the Autonomous University of Barcelona. E-mail: valentinamag@outlook.it.
} 


\section{Introduction. The concept of citizenship within the borders of a nation state}

The ongoing debates about citizenship can be traced back to the the ideas developed by the British philosopher Thomas H. Marshall.

In 1950, Marshall published an essay entitled "Citizenship and Social Class", in which he elaborated a renewed concept of citizenship. He conceived it as an evolutionary aggregate of political, social, and civil rights that individuals gain progressively through their recognition by the Nation State and the legal system, to which they are subject. Such a Nation State is a territory of exclusive and exclusivist sovereignty, in which the only prospect of cultural integration is sheer assimilation into the dominant culture. ${ }^{1}$

However, Marshall did not conceive citizenship solely as a legal status defined by a set of rights and responsibilities. In his view, the concept of citizenship was also closely linked to that of "identity", since it creates in individuals a sense of belonging, an identity bond towards the nation, thereby drawing boundaries between foreigners and nationals.

Consequently, the concept of citizenship has two constitutive elements: rights and identity. Each of them "must be experienced in a geographical context, regardless of how this geographical context is defined".

Since the seventies, however, the foundations and the viability of the "Welfare State" were questioned because of the serious economic crisis and the first glimpses of the globalisation process, which pointed at the bond between nationality and citizenship that had been built according to the standards of the liberal state. ${ }^{3}$ In this context, the impact of migration and the rooting of different cultural communities in the change process of the States made clear that the traditional concept of citizenship, developed by Thomas H. Marshall and based on the idea of a coherence between a culture and a nation, would not apply to contemporary social systems anymore, since it appeared to be inadequate to accommodate the challenges of the new multi-ethnic, multi-confessional and multi-cultural societies.

The changing nature of our societies opened, therefore, a path to the category of "integration", which is set as the new imperative need of our time. This way, we get to the European integration process and to the very concept of European citizenship, which treasures the indisputable virtue of being the first political and legal materialisation of a citizenship at a transnational level.

\section{European citizenship}

The background of European citizenship has its origins in the Treaty of Rome of 1957, in which the right of workers to freedom of movement within the territory of the Community was recognised.

Later on, in the Tindemans report of 1976, it appeared a chapter titled "A citizen's

\footnotetext{
${ }^{1}$ Carlos Arce Jiménez, Los derechos politicos de los residentes extranjeros: la ciudadanía inclusiva (Sevilla: Defensor Del Pueblo Andaluz, 2012), 32 [free translation].

2 Percy B. Lehning, "European citizenship: towards a European identity?', Working Paper Series in European Studies, volume 2, no 3, (1999): 6.

${ }^{3}$ Luigi Ferrajoli, Derechos y garantías. La ley del más débil (Madrid: Trotta, 1999), 18 [free translation].

${ }^{4}$ The report by Mr. Leo Tindemans, Prime Minister of Belgium, to the European Council, commonly called the Tindemans Report was published in the Bulletin of the European Communities, Supplement 1/76.
} 
Europe", in which the Belgian Prime Minister, Leo Tindemans, proposed to extend the individual rights recognized in the Treaty of Rome, in order to encourage greater integration among Europeans. The proposals put forward in the above-mentioned report obtained a first materialisation in 1979, when, for the first time, members of the European Parliament were directly elected by universal suffrage. ${ }^{5}$

In 1990, the European Council introduced the concept of European citizenship, as a fundamental status granted to every Member States' nationals that would be later incorporated into the Treaty on European Union (TEU) signed in Maastricht on 7 February 1992. According to Article 9 thereof "[e]very national of a Member State shall be a citizen of the Union. Citizenship of the Union shall be additional to and not replace national citizenship".

It follows from the above, first, that European citizenship "has a derivative nature since holding the nationality of a Member State is a prerequisite for acquiring it". ${ }^{6}$ Second, EU citizenship is "complementary", as it is not meant to replace national citizenship.

It is ultimately a sui generis citizenship, ${ }^{7}$ which overlaps the Member State's nationality without affecting its political and legal effectiveness. Some authors define it correctly as a "federal" or "multilevel" citizenship, governed by the national legislation of the Member States as well as "the direct and indirect dimensions of Union citizenship", where the "direct" dimension reflects the legal relationships existing between Union citizens and the EU, while the "indirect" dimension refers to the relationships between a Member States' nationals and the other Member States. ${ }^{10}$

It can be argued, therefore, that the EU has a "multiple demos", composed by the national demoi of its Member States that constitute, together, a shared European

The full text is available at http://aei.pitt.edu/942/, (last accessed on 21/11/2017).

${ }^{5}$ Before the introduction of direct elections, Members of the European Parliament were appointed by each of the Member States' national parliaments. All Members thus had a dual mandate. The Summit Conference held in Paris on 9 and 10 December 1974 determined that direct elections "should take place in or after 1978" and asked Parliament to submit new proposals to replace its original draft convention of 1960. In September 1976, the Decision and Act on European elections by direct universal suffrage were signed in Brussels. Following ratification by all Member States, the Act entered into force on July 1978, and the first elections took place on 7 and 10 June 1979.

"Samantha Besson and André Utzinger, "Towards European Citizenship", The Journal of Social Philosophy, vol. 39, nº 2, (2008): 190.

${ }^{7}$ As it is explained in the Third Report from the Commission on Citizenship of the Union (COM/2001/0506): "When considering the scope of citizenship of the Union, attempts to draw parallels with the national citizenship should be avoided. Because of its origins and the rights and duties associated with it, citizenship of the Union is sui generis and cannot be compared to national citizenship of a Member State".

${ }^{8}$ Basically, the concept of federal citizenship describes the citizen status at a federal level that implies the recognition of some federal rights, in addition to other citizenship rights provided to individuals by their nation state. In this vein, Moro argues that: "The realization of Europe will highlight the pluralistic aspect as a new concept of citizen. The best way to define the new kind of citizen is European federal citizen" [free translation]. See Domenico Moro, "La cittadinanza federale europea",The Federalist a political review, year XXII, (1980), No 1-2, 100. A similar approach is suggested by C. Schönberger, who argues in favour of thinking about citizenship in the Union from a federal perspective, which means that we must "free ourselves from the unitary state-centred categories and consider the possibility of tiered, nested citizenships in federal systems". See C. Schönberger, European Citizenship as Federal Citizenship: Some Citizenship Lessons of Comparative Federalism, (2007), quoted by J. Shaw, "Citizenship: Contrasting Dynamics at the Interface of Integration and Constitutionalism”, EUI Working Paper RSCAS vol. 60, n. 4 (2010).

9 See Eva-Maria Poptcheva, Multilevel Citizenship: The Right to Consular Protection of EU Citizens Abroad (Brussels: Presses Interuniversitaires Europeennes, 2014), 85.

${ }^{10}$ Eva-Maria Poptcheva, Multilevel Citizenship..., 83. 
demos, ${ }^{11}$ none of these excluding the other. In this vein, Besson and Utzinger notice that "European citizens are not only the citizens of a national state taken individually, but, when they deliberate on issues of European interest, they are citizens of each state 'qua' key component of the broader European polity. (...) In the light of this conception, citizenship in Europe amounts to more than the sum of its parts. It is a Union of peoples, that is, a true "demoi-cracy". ${ }^{12}$

The status of a European citizen implies the acknowledgment of several rights to the nationals of the EU Members States (EUMS). This set of rights, according to Article 20(2), can be grouped into four categories: the right to move and reside freely within the territory of the Member States (Article 21, TFEU); the right to vote for and stand as a candidate in elections in the European Parliament as well as in municipal elections in the Member State in which they reside, under the same conditions as nationals of that State (Article 22 TFEU); the right to enjoy, in the territory of a third country where the Member State of which the citizen is a national is not represented, the protection of the diplomatic and consular authorities of any Member State on the same conditions as the nationals of that State (Article 23 TFEU); the right to petition the European Parliament and apply to the European Ombudsman to investigate cases of alleged maladministration by EU institutions and bodies (Art. 24 TFEU).

The succeeding Treaty of Amsterdam 1997 integrates the civil rights of the EU's citizens by adding: the right to address the European institutions in any of the official languages of the EUMS and receive an answer in the same language (fourth paragraph of Article 24 TFEU) and the right of access European Parliament, European Commission, and Council documents under certain conditions (Art. 15 TFEU).

The lack of uniformity in the field of fundamental rights in the Community sources imposed, however, the need to adopt a single coherent text that could collect organically the civil, economic, and social rights arising from the common constitutional traditions of all Member States. This project found its fulfillment in 2000, when the Charter of Fundamental Rights of the European Union was proclaimed in Nice. ${ }^{13}$ This Charter contributed not only to giving visibility and clarity to the fundamental rights, but also to develop the concept of European citizenship, which was enshrined in Title $\mathrm{V}$ thereof (Articles 39 to 46).

At a later stage, thanks to the coming into force of the Lisbon Treaty in December $1^{\text {st }}, 2009$, the Charter acquired the same legal standing as the Treaties, becoming binding on EUMS. However, due to the conservative attitude of the States, there was no significant progress around issues of citizenship, except for the creation of the legal basis necessary to implement the right of citizens' initiative before the European Commission. ${ }^{14}$

\footnotetext{
${ }^{11}$ Raphael Durán Muñoz and Magdalena Martín Martinez, La integración politica de los inmigrantes (Malaga: Editorial Comares, 2008), 116, [free translation].

${ }^{12}$ S. Besson and A. Utzinger, "Towards European....". See footnote no. 7.

${ }^{13}$ The Charter of Fundamental Rights of the Union was proclaimed jointly by the President of the European Parliament, the President of the Council and the President of the Commission, in a ceremony at the time of the Nice European Council on 7 December 2000. It was published in the Official Journal of the European Communities, [43] [43] OJ C 364, 18 December 2000.

${ }^{14}$ With the Lisbon Treaty, the European Union (EU) took a great step towards the citizens by offering them the opportunity of participating directly in the setup of the legislative development: thanks to the European Citizens' Initiative, a million of citizens of the Union can ask to the European Committee to present a legislative proposal. The initiatives that gain enough support can contribute to steer the legislative direction of the EU.
} 
Furthermore, in addition to the citizens' rights that are explicitly mentioned in the Treaties, there is a whole series of fundamental rights and obligations which stem from the case-law of the Court of Justice of the European Union (CJEU) and the European Court of Human Rights (ECtHR) in Strasbourg, that adjudicates upon the European Convention of Human Rights and Fundamental Freedoms (henceforth, ECHR), and the Constitutional traditions of the Member States. The benefits of Union citizenship are, thus, not limited to the rights conferred by Articles 18-25 TFEU, which, inter alia, do not constitute an exhaustive catalogue of rights. By using the expression "inter alia", Article 20(2), TFEU leaves in fact the possibility of expanding this catalogue, through the "special procedure" foreseen by Article 25 of the same Treaty, which requires unanimity in the European Council, the prior approval of the EU Parliament and the consent of all Member States in order "to strengthen or to add further rights to those listed in Article 20(2)". It follows that EU citizenship is evolutionary; it is rather a process than a status suggesting a static situation ${ }^{15}$ and can always expand to new rights together with the expansion of the scope of the EU Treaties.

However, it must be noted that the Union citizenship is not only a legal status made up of rights and duties. It is also a sense of political identity, a sense of belonging that facilitates coexistence and integration within the EU. As pinpointed by the European Commission in its Third Report on Union Citizenship (2001), "[c] itizenship of the Union is both a source of legitimation of the process of European integration, by reinforcing the participation of citizens, and a fundamental factor in the creation among citizens of a sense of belonging to the European Union and of having a genuine European identity".

This identity does not simply find its roots in a shared past or in an inherited common culture, nor is based on the unity around one single language, religion or socio-political conception. As effectively underlined by Habermas ${ }^{16}$ in his theory known as "constitutional patriotism", it is, rather, a form of postnational identity based on shared values and common moral, legal, and political principles. Such identity dissociates from the background of a shared past in terms of national history, and it is set as the only remedy available to the citizens of supranational political organizations, like the European Union, which obviously do not share a common national history, but rather a past characterized by conflicts and wars between the Nation States. ${ }^{17}$

These values and principles, constitutive elements of the European identity, are set out in Article 2 and 6 of the Lisbon Treaty, inter alia. According to Article 2 of the aforementioned Treaty, "[t] he Union is founded on the values of respect for human dignity, freedom, democracy, equality, the rule of law and respect for human rights, including the rights of persons belonging to minorities. These values are common to the Member States in a society in which pluralism, non-discrimination, tolerance, justice, solidarity and equality between women and men prevail'.

The following Article 6 (paragraph 1) makes explicit reference to the Charter of Fundamental Rights and also (Art. 6, paragraph 2) the fundamental rights, as ensured by the ECHR and the constitutional traditions common to the Member States that, together, shall all be part of the Union's law as "general principles".

\footnotetext{
${ }^{15}$ E. Poptcheva, Multilevel Citizenship..., 86.

${ }^{16}$ Jürgen Habermas, Identidades nacionales y postnacionales (Madrid: Tecnos, 1989), 118.

${ }^{17}$ José Luis López De Lizaga, "Ciudadanía e identidad nacional”, in R. Lorenzo and R. Benedicto (coords.), Educación cívica: democracia y cuestiones de género (Barcelona: ICARIA, 2010), 14 -16.
} 
This way, a tripartite interrelation between the rights system of the European Union, of the European Council and the Constitutions of the Member States is created, which sets up a "multilevel, comprehensive and constantly evolving system of fundamental rights in Europe". ${ }^{18}$ This system confers a constitutional dimension to Union citizenship and builds up a legal community, or a "citizenship of rights" ${ }^{19}$ which will be further developed by exercising the Union citizenship status through enjoyment of the rights conferred upon Union citizens by the EU Treaties. ${ }^{20}$ In other words, it is the exercise of citizens' rights that will fill out with content the fundamental status of European citizens. And "this idea of a legal community of rights and duties (established by the EU and not by a singular Member State) promotes the sense of belonging to the Union among individuals". ${ }^{21}$

Framing the issue this way, this would enable one to conclude that Europe is not simply a set of rules, nor a manual of protocol and procedures to follow. Instead, it should serve to exonerate the fact that our Union reflects a union of values and principles enshrined in the Treaties, whose respect is non-negotiable. ${ }^{22}$

Consequently, the present paper rejects the idea that people in Europe cannot develop any sort of European identity. The so-called "no-demos thesis", according to which European citizenship and democracy are doomed to fail as long as there is no European demos shared among the Member States, would not be suitable to describe the development that Union citizenship is undergoing.

Admittedly, citizenship of the Union does not operate within the boundaries of a federal State and yet, within the framework of the EU, the concept of citizenship, "both as a legal status and as a bundle of rights, has moved beyond the boundaries of a nation state". 23

\section{Europe, between Eurosceptics and Europhiles}

Against this background, it becomes clear that when we talk about European citizenship, we are concerned with both constitutive elements of the classic concept of citizenship (rights and identity), although they conform to totally innovative parameters. However, at a time like the present, when nationalist and xenophobic feelings against the EU are on the rise and "the national egoism is becoming an attractive alternative to integration", ${ }^{24}$ the European identity struggles to attain a legitimate status

\footnotetext{
${ }^{18}$ Teresa Freixes, "Derechos fundamentales en la unión europea. Evolución y prospectiva: la construcción de un espacio jurídico europeo de los derechos fundamentales", Revista de derecho constitucional europeo, $\mathrm{n}^{\circ} 4$ (2005): 43-86 [free translation].

${ }_{19}$ Alessandra Silveira, Mariana Canotilho and Pedro Madeira Froufe, Citizenship and Solidarity in the European Union. From the Charter of Fundamental Rights to the Crisis, the State of the Art (Brussels: Presses Interuniversitaires Europeennes, 2013), 483.

${ }^{20}$ E. Poptcheva, Multilevel Citizenship..., 86.

${ }^{21}$ Alessandra Silveira, "Citizenship of rights and the principle of the highest standard of fundamental rights' protection: notes on the Melloni case”, in Elspeth Guild, Cristina J. Gortázar Rotaeche and Dora Kostakopoulou (eds.), The reconceptualization of European Union citizenship. (Boston: Brill Nijhoff, 2014), 298.

${ }^{22}$ See in this sense T. Freixes, "Derechos Fundamentales en la Unión Europea...", footnote 19 arguing that: "This configuration of the fundamental rights as Union's values does not have a sheer declaratory character since it is a key condition that precludes the admission in the EU to third countries that do not accept them, so that its violation can be reason of penalty for the Member States that infringe them, which might involve the loss of the rights of participation and vote in the community institutions and even the expulsion from the Union itself", 56, [free translation].

${ }^{23}$ Dimitry Kochenov, "IUS tractum of many faces: European Citizenship and the difficult relationship between status and rights", Columbia Journal of European Law, vol. 15, $\mathrm{n}^{\circ} 2$ (2009), quoted by Poptcheva, ibid., 88.

${ }^{24}$ European Council, "United we stand, divided we fall": letter by President Donald Tusk to the 27 EU heads
} 
in the eyes of the citizenry. The question, then, is whether the European citizen does actually exist more than just in text.

The surveys carried out regularly by the European Commission demonstrate that the Europeanist consensus is not unequivocal and ranges between various factors.

On this matter, Brexit itself emphasizes in different ways how much our societies are divided and teaches us that these divisions are something that we really need to recognise and take seriously.

As underlined by Betts, in a brilliant TED talk, ${ }^{25}$ it is well known that the vote about Great Britain's staying (or not) in the EU split among age, education, class and territory. Young people did not go to the polls in great numbers and only those who wanted to remain took part in the vote. Older people actually wanted to leave the European Union. Geographically, London and Scotland were the most committed to being part of the EU, whilst in other parts of the country, there was very strong ambivalence.

If we analyse the reasons of those who wanted to leave, we see three major factors in the opinion polls that led to this outcome. The first was simple: opponents of the EU argued that it is a dysfunctional economic entity. In this sense, the government's austerity policies introduced in response to the 2008 financial crisis and the objective economic inequality between the lives of southern European countries and Germany (that enjoys one of the lowest rate of unemployment in Europe ${ }^{26}$ corroborated the idea that Europe was an economic disaster.

The concern about immigration was the second important driver for the "leave" vote ${ }^{27}$ especially emphasized in inquiries by those segments of the native population residing in more culturally homogenous parts of the country. And if, from one side, this reflects ideas of fear and alienation, from the other side, it adds fuel to ultranationalist political parties, entailing a retreat to the boundaries that many of us would reject.

Thirdly, Britain's vote to leave the EU was the result of the wide dissatisfaction with the political establishment, which reflected the widespread feeling among the citizenry that nobody could represent them in the political arena. For many, Brexit was, therefore, a protest vote against the British elite.

Admittedly, all of these factors, namely, the disaffection towards the political class as well as the concern about immigration and the doubtful capacity of the EU to address the economic problems, are not exclusively British phenomena; they are rather constants that are sweeping Europe and many other liberal democracies. That is reflected in the dangerous rise of populist rhetoric and nationalist movements around the world and shows that "the specter of Brexit is in all of our societies". ${ }^{28}$

of state or government on the future of the EU before the Malta summit (31.1.2017)" Available at http://www. consilium.europa.eu/en/press/press-releases/2017/01/31/tusk-letter-future-europe/\# (last accessed on $23 / 11 / 2017)$.

${ }^{25}$ Alexander Betts, Why Brexit happened and what to do next? (2016), /Video file]. Available at: https:// www.ted.com/talks/alexander_betts_why_brexit_happened_and_what_to_do_next (last accessed on 23/11/2017).

${ }^{26}$ Eurostat estimates that among the Member States, the lowest unemployment rates in September 2017 were recorded in the Czech Republic (2,7\%), Germany (3.6 \%) and Malta (4.1\%). The highest unemployment rates were observed in Greece (21.0 \% in July 2017) and Spain (16.7\%).

${ }^{27}$ John Mauldin, “Three Reasons Brits Voted For Brexit” (2016), retrieved November 25, 2017 from: https://www.forbes.com/sites/johnmauldin/2016.

${ }^{28}$ John Mauldin, “Three Reasons Brits...". 
For this reason, facing the wound of Brexit, it is right to ask ourselves how we should respond collectively. For those of us who care about creating liberal, pluralist and open societies, we urgently need a new vision, the vision of a tolerant and inclusive Europe that brings people together instead of leaving them behind.

We must admit that the EU is still seen as an agenda of the elite, instead of something that benefits all of us. Hence, we must reclaim it on a much more inclusive basis than today. The challenge ahead is that we need to find a new way to narrate European integration to all those who do not feel part of the project and that do not understand the pressing need for being "united in diversity". We must acknowledge that those who, maybe, have not been to university, who have not necessarily grown up with the Internet or who do not get the opportunity to travel, might not find fascinating the narration that we, by contrast, find persuasive. So, the questions are: how can we reach this target? How can we maintain the balance, on the one hand, broaching fear and alienation while, on the other hand, rejecting vehemently to give in to xenophobia and nationalism? How can we assure that everyone can benefit from the totality European integration? These are the questions for all of us. For my part, I would like to share four ideas as a starting point.

This vision of an inclusive Europe must begin with the recognition of the positive benefits that the EU has on our daily lives. What is striking about Brexit is the gap between public perception and empirical reality, widespread ignorance about the effects of the withdrawal of the United Kingdom from the EU. The first thing is to promote a monumental information campaign about the cost of the non-Europe and stimulate the debate about European issues.

In Italy, just as in Spain (and in most of the Member States), there is no debate simply because no one talks about Europe; which is partly because of the culpable indifference of the media and partly, because of the selfish silence of the national political powers. In order to break that silence, it is essential to build a common space for the dissemination of information in Europe, which makes the existence of a common European public opinion possible.

Currently, we count on numerous sources of information about the EU, but not on a common source of information that works as a "net". We must coordinate common programs by using the public televisions; channels like Euronews should be accessible to all and not only to the internet users. However, we all know that the social change is not going to be the result of only having more information, but of making something with it.

The second idea is, therefore, to create a bridge between citizens and institutions. The European Union would otherwise, be reduced to a set of markets considering that, for the moment, the integration progress is much more developed on an economic level than on a political one. Let us, then, see how we can bring people into this process.

In ancient Greece, participation took place in the Agora, which meant both a market and a place where there was political deliberation. At the time, market and politics were inextricably woven, and it was an accessible and transparent place. $^{29}$ Nowadays, instead, we have unified our markets, but we do not have a political union inside the EU. So, our politicians are confined to local politics, while citizens step

\footnotetext{
${ }^{29}$ George Papandreou, Imagine a European democracy without borders, (2016). /Video file]. Retrieved from: https://www.ted.com/talks/george_papandreou_imagine_a_european_democracy_without_ borders (last accessed on 23/11/2017).
} 
away from the political life, accepting passively and uncritically the decisions of the majority. And apathy, as well as protest, ensues. The question then is: how can we reunite the two halves of the Agora?

Is it precisely here where the role of the civil society fits perfectly in, as a key factor in strengthening the sense of belonging between the social actors and contributing to the development of a democratic and valuable politeya europea. ${ }^{30}$

Democratic civil society means a pluralistic and differentiated participation space, where it is possible to develop the civil fabric of a society through the creation of organizations, collectives, entities, informal groups, nets, platforms and social movements ${ }^{31}$ that, as a whole, serve as mediators between individuals and State. Participating in associative networks stimulates the mutual identification of the members; it builds trust, reciprocity and "moral density". ${ }^{32}$ In this sense, civic associations contribute to the development of the civic habits.

So, against the loss of confidence in the mechanisms of representative democracy and the disaffection towards the European project, less formal modalities of participation could be more effective. However, the change must not be led by today's politics. The rebirth of the passion for the European project will come from all those who participate in this exchange of ideas; anyone, who stands up to injustice and inequality and to the preachers of racism instead of solidarity, of dogma instead of critical thinking, of populism instead of democracy, of exclusion instead of integration. We need to gather a critical mass of intelligences and passions able to collect in a manifest the need that everyday political chronicle does not perceive. Since there will be no more and better Europe if millions of European citizens do not claim it, fighting against the nationalists' manipulation of fear and retrieving the dream of our Founding Fathers.

Third: exchange and mobility programmes must be promoted. Every project that stretches beyond national borders is essential to build a European identity, being a means of intercultural and social integration, which facilitates mutual knowledge among civilizations and people, removing internal and external boundaries and prejudices.

We currently count on several programmes intended for young Europeans. Among them, I will just mention the Erasmus, from which I have personally benefited. It is well known that the Erasmus is a "gym" of European citizenship, whose success in this respect has been fully proven as well as the numerous advantages derived therefrom in terms of occupation and professional success. However, every year the applications to this programme exceed the universities' budgets, so that many students have no access to the studies grant and cannot take advantage of the experience.

For a good functioning of such initiatives is then essential to increase the EU support and, to this effect, some fiscal reforms are needed. The European income is still too narrow: 130 billion euros is not enough for creating new policies and for promoting mobility programmes. Not to mention the fact that the EU also lacks financial autonomy. Nowadays, citizens pay $100 \%$ of the taxes to their State and to

\footnotetext{
${ }^{30}$ Ramón Vargas Machuca, “Representación”, El saber del ciudadano (Madrid, 2008), 168-176.

${ }^{31}$ Jean L. Cohen and Andrew Arato, Civil society and political theory (Massachusetts: The MIT Press, 1994), 456.

${ }^{32}$ Michael Baurmann, El mercado de la virtud. Moraly responsabilidad social en la sociedad liberal (Barcelona: Gedisa, 1998), 105-106.
} 
the local authorities, "there is a top-down fiscal federalism, but a bottom-up approach does not exist' ${ }^{33}$ After all, there would be no need of increasing the taxes in order to create a European fiscal union because it would be enough to direct a small part of the state incomes to the EU. This would justify, among other things, an eventual balance control of the EU from the European Parliament. Creating a European taxation would contribute significantly to achieve these goals.

The forth idea I want to share is related to education. So far, there is no common legislation that obliges one to incorporate certain contents in the school curricula of the Member States. Education is still left exclusively in the hands of the States. In this regard, the Union's action is clearly guided by the principle of subsidiarity, of completing the states action rather than intervening in the educational sphere of each one of them. This is why the laws that regulate our educational systems are still formulated and applied in the Member States under exclusive internal criteria, while we could think that there are enough common goals and elements to justify a European framework law in the educational sphere, able to set a common structure, goals and minimum contents, ${ }^{34}$ that should be undertaken both at primary education level and at university level. Why not create the first big public European Universities? And why not incorporate programmes of civic education and of "European humanism" in every Member State? If the EU had more effective competences in the field of education, it would be easier to train the future European citizens.

\section{Concluding remarks}

"The challenges currently faced by the European Union are more dangerous than they have ever been since the signing of the Treaty of Rome". ${ }^{35}$ At present, internal and external threats corrode the idea of the Union: Brexit's wound, the rise of nationalist movements, the unbridled populism and the new geopolitical situation in the world and around Europe impose us to react.

We are Europeans because our long belligerent history taught us to prefer the peaceful resolution of controversies. We do not send our soldiers to death without uniforms, nor our youths to blow themselves up in public places. But we are aware that there is no peace in the world and we know how unstable our neighbourhood is, in Ukraine, Russia, Syria, Iraq, Lebanon and the Sahel. Facing an increasingly determined China, the aggressive politics of Russia, the terrorism of radical Islam, as well as the worrying statements of the new American administration of Donald Trump, we must form a common front.

Since the beginning of 2015, more than a million people have been forced to cross the route of the Mediterranean in order to escape from war. They have risked their lives to arrive in Europe. According to the latest figures released by the UN's refugee agency, 4,337 people are believed to have drowned since September 2016 while attempting to reach European shores. ${ }^{36}$ All of this is not humanly acceptable. We cannot let it fall into

\footnotetext{
${ }_{33}$ Pietro Graglia. "Per un Parlmento Europeo piu' forte” retrived November 25, 2017 from: https:/ /www. eurobull.it/Per-un-Parlamento-europeo-piu-forte-Intervista-a-Piero-Graglia [free translation].

${ }^{34}$ Jaume Sarramona López, "Nación Ciudadanía europea y educación", Formar Europeos: algunos modelos de aplicación en España. Documento de Trabajo. Academia Europea de ciencias y artes (2005), 15 -22 [free translation].

${ }^{35}$ European Council, "United we stand, divided we fall...". See footnote 26.

${ }^{36}$ A further 4,185 people died in the previous 12 months, from September 2015 until the end of August 2016. These data have been recovered from the Spanish Committee of Aid to Refugees
} 
total indifference and get used to others' suffering. We should remind ourselves that we are Europeans because we consider refugees and asylum seekers as victims, rather than as threats. Our solidarity is not selective and is the base of the common European home. Therefore, facing the massive arrival of immigrants and all the other challenges we deal with, it is essential to keep as goal an increasingly strong integration.

We should reflect on the present difficulties and look to the future to make the European project advance. No country by itself can withstand such tensions. By acting individually, we will be shut out from the global dynamics. Europe is our only possibility of surviving. So welcome the idea of a two-speed Europe, in which there is a sufficient core of countries willing to engage with new political aim at strengthening the Union, which could give better responses to the internal and external challenges that the European society has to face. This core of countries is meant to be the "motor" of the Union and, later on, there will be a moment when we will all walk together again to take the great step towards a federal state.

More Europe does not simply mean to give more power to Brussels. It is actually giving more power to the European citizens, thus making of Europe a project of and for the people.

The Europe Union is a project worthy of being built. "Thus, take this action over, bringing in it your fervour and even your grain of madness". A. Spinelli ${ }^{37}$

(CEAR)'s report titled: “Movimientos migratorios en España y Europa”, retrieved on November 26, 2017 from: https:/ /www.cear.es/wp-content/uploads/2017/02/Informe-rutas-migratorias.pdf.

${ }^{37}$ The original quote was: "Sappiate, dunque, assumere quest'azione, portando in essa il vostro fervore, e anche il vostro grano di follia" [free translation]. 